\title{
Jordan: Variationer over velkendte temaer
}

\section{Af Morten Valbjørn}

Forholdet mellem kontinuitet $0 \mathrm{~g}$ forandring har udgjort et af de centrale temaer i debatten om implikationerne af de arabiske revolter, der tog sin begyndelse for godt seks år siden. I Jordan har kontinuiteten dog været mere fremtræedende end forandringen.

Først handlede debatten om demokratisk forandring og autokratisk kontinuitet. $\mathrm{Da}$ det stod klart, at Mellemøsten fortsat ikke var ramt af den store demokratisk bølge, nuanceredes debatten til at handle om forandring og kontinuitet $i$ autokratiske regimer. Var der tale om en arabisk version af 'tilbage til fremtiden' i den forstand, at situationen var som før 2011, og at der blot var tale om 'Mubarakisme uden Mubarak'? Eller markerede de arabiske revolter et fundamentalt brud med tidligere tiders form for autokrati, som nu var ved at blive afløst en helt ny, mørkere og mere voldelige form for autokrati, der ville vise sig endnu mere modstandsdygtig over for demokrati end tidligere varianter?

Endeligt var der også dem, som mente, at debatten skulle udvides fra at hand- le om de mellemøstlige staters overlevelsesdygtighed til et mere fundamentalt spørgsmål, om hvorvidt vi stod over for afslutningen på det seneste århundredes 'Sykes-Picot system', og hvilken form for (u)orden og politisk organisering, der i givet fald ville følge efter.

De forskellige lejre i disse debatter vil alt afhængigt af, hvor man vender blikket, kunne finde delvis støtte til hver deres position. Frem for at tale om 'ét arabisk forår’ står det i dag derfor også klart, at det giver bedre mening at tale om 'de arabiske revolter'. Selvom alle dele af den arabiske verden blev påvirket af begivenhederne i 2011, har graden og formen været vidt forskellig, og landene har i de følgende seks år derfor også bevæget sig i forskellige retninger, der har været præget af varierende grader af kontinuitet og forandring. Forenklet kan man tale om fire forskellige veje: 1) en skrøbelig demokratisk udvikling (Tunesien), 2) statssammenbrud (fx Syrien, Libyen, Yemen), 3) en ny, mørkere og mere voldelig form for autokrati (Ægypten, Bahrain), og 4) opgradering af en relativt velkendt form for auto-

Morten Valbjørn, lektor, Institut for Statskundskab, Aarhus Universitet. Han er forfatter til utallige artikler og har bidraget til en række bøger om Jordan og Mellemøsten. 
kratisk styre (Kuwait, Algeriet, Marokko og Jordan).

Det er denne sidste variant, som er omdrejningspunktet for herværende artikel, der angår Jordan, hvor kontinuiteten har været mere fremherskende end forandring. Selvom det lille hashemitiske monarki også oplevede protester tilbage i 2011, har Kong Abdallah II ikke blot formået at klare sig igennem de arabiske revolter, men det er også sket med brug af relativt velkendte midler. Det betyder ikke, at der ikke har været nogen forandringer i Jordan siden de arabiske revolter, men $i$ vidt omfang er der tale om variationer over velkendte temaer.

\section{Jordan og de arabiske revolter}

For dem, der havde rettet blikket mod Jordan i månederne før, den siden så berømte tunesiske grønthandler Mohamed Bouazizi i december 2010 satte ild til sig selv, var der ikke mange tegn på, at Jordan stod over for nogen større protestbølge eller politiske aktivisme. Det politiske klima var præget af udtalt apati, og der var kun få, som interesserede sig for eller tillagde parlamentsvalget i december 2010 nogen betydning.

Uden for den formelle politiske scene havde der ganske vist været tegn på, at noget kunne være i gære. I løbet af efteråret havde der været forskellige former for optøjer og voldelige sammenstød, som pegede på voksende spændinger og utilfredshed. Disse sammenstød, som især fandt sted mellem medlemmer fra forskellige stammer, var dog kendetegnet ved, hvad nogle iagttagere beskrev som 'social vold' i den forstand, at de sjældent var forbundet med eksplicitte politiske krav eller visioner endsige nogen tro på, at man gennem politisk aktivisme kunne skabe reelle politiske forandringer. De adskilte sig her- ved fra, hvad der få måneder senere ville komme.

Jordan var blandt de første arabiske lande, hvortil de arabiske revolter spredte sig efter at være begyndt i Tunesien og Egypten. De første demonstrationer, som arrangørerne navngav 'Vredens Dag', begyndte allerede den 14 . januar 2011, dagen efter den tunesiske præsident Ben Ali var flygtet. I de første dage svirrede det faktisk med rygter om, at kong Abdallah og dronning Rania snart skulle på 'palace hunting in Jeddah', som det blev formuleret $\mathrm{i}$ et tweet på de sociale medier.

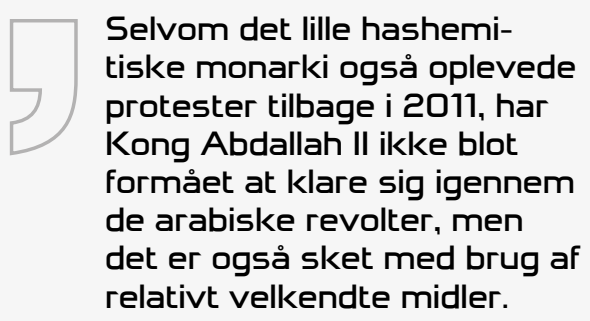

Det blev dog ikke tilfældet, og i modsætning til andre steder i den arabiske verden stod det jordanske monarki aldrig på randen af sammenbrud. Selvom der $i$ en lang periode var ugentlige fredagsprotester, havde demonstrationerne sjældent flere end 10-15.000 deltagere og nåede således aldrig samme størrelse som i fx Egypten, Tunesien og Bahrain. De forblev også fredelige og eskalerede ikke til den form for 'begravelses-cyklus', som man så i Syrien, hvor begravelsesoptog for dræbte demonstranter udviklede sig til nye demonstrationer med sammenstød og flere dræbte.

I modsætning til fx Tunesien og Egypten, hvor demonstranterne tidligt erklærede, at 'folket ønsker at vælte regimet', var de jordanske demonstranters krav reformistiske frem for revolutionære. Man øn- 
skede forandringer inden for rammerne af det hashemitiske monarki. De mest vidtgående krav var således, at Jordan skulle være et reelt konstitutionelt monarki baseret på en videreudvikling af 1952-forfatningen.

\section{$\square$ \\ I modsætning til fx Tunesien og Egypten, hvor demon- stranterne tidligt erklærede, at 'folket ønsker at vælte regimet', var de jordanske demonstranters krav re- formistiske frem for revolu- tionære.}

Meget karakteristisk var slagordene ved demonstrationerne heller ikke rettet mod kongen, men mod premierministeren og regeringen, og handlede i vidt omfang om behovet for større social retfærdighed, lige muligheder for alle og et opgør med den udbredte korruption. Demonstranterne udgjorde endeligt også en meget heterogen gruppe bestående af den traditionelle politiske opposition domineret af venstreorienterede grupper og det Muslimske Broderskab, nye ungdoms-og studenterbevægelser, transjordanske stammer, salafister og endelig veteraner fra militæret. Selvom de var enige om, at der var behov for forandringer uden revolution, herskede der meget delte meninger om det nærmere indhold i de ønskede politiske og $ø$ konomiske reformer. Det fremstod næsten som om, at det eneste demonstranterne for alvor var enige om var, at de alle støttede kongen.

\section{Regimets respons}

Ud over demonstranternes heterogene profil og moderate krav spillede den regionale udvikling også en rolle for, hvorfor protesterne ebbede ud. Indledningsvist var der megen entusiasme og tiltro til, at det var muligt at skabe positive forandringer gennem politisk aktivisme. Stemningen ændrede sig imidlertid allerede i slutningen af foråret 2011, da de arabiske revolter for alvor blev blodige i Bahrain, Syrien og Libyen, og ikke mindst da flere lande efterfølgende blev kastet ud i tragiske borgerkrige, som i Jordan gav mindelser tilbage til den kortvarige 'Sorte September-borgerkrig' i 1970.

Derudover er det selvsagt også vigtigt at have blik for regimets respons på de uventede protester. Sammenlignet med en række andre arabiske regimer var det jordanske dygtig til på fleksibel vis at håndtere protesterne gennem en flerstrenget strategi. Man var meget opmærksom på at undgå, at det udviklede sig til voldelige konfrontationer, bl.a. ved at indsætte almindeligt politi frem for det effektive, men også ofte ganske hårdhændede $\mathrm{Da}$ rak-uropoliti.

Samtidigt forsøgte man at tage luften ud af protesterne gennem nye økonomiske subsidier på fødevarer og lønstigninger til offentligt ansatte og militæret, kombineret med delvise indrømmelser i forhold til demonstranterne krav. For eksempel blev den udskældte premierminister Samir Rifai fyret, og hans afløser Bakhit, der havde fàet pålæg om at iværksætte, hvad kongen betegnede som 'virkelige politiske reformer, lancerede straks en række reforminitiativer.

Flere iagttagere hæftede sig dog ved, at der var noget påfaldende velkendt ved alle disse såkaldte nye initiativer. Det mindede på mange måder om kong Husseins reaktion på de tilsvarende store protester tilbage i 1989, hvor det dengang var den ældre Rifai, som blev ofret som premierminister. Trods løfter dengang om, at Jordan nu ville træde ind i en helt ny demokratisk æra, viste de mange reforminitiativer sig imid- 
lertid at blive indledningen på, hvad der er blevet betegnet som Jordans 'transition to nowhere'.

I de følgende to årtier befandt Jordan sig således formelt i en demokratiseringsproces, men uden at blive mere demokratisk. Ifølge Freedom House’s årlige demokratioversigt var Jordan faktisk mindre frit i 2010 end i 1989. Denne form for kontinuitet bag tilsyneladende forandringer var et fremtrædende tema i mange diskussioner om jordansk politik før 2011, og det synes ligeledes at være meget dækkende for udviklingen i Jordan gennem de seneste seks år.

\section{Et liberaliserende autokrati}

Liberaliserende autokrati var et analytisk begreb, som blev flittigt brugt i diskussioner om Jordan før 2011. Denne regimeform er kendetegnet ved, at der altid tales om demokrati og politiske reformer, som dog ofte forbliver tomme løfter; og konkrete politiske reformtiltag bliver i reglen fulgt af andre tiltag, der i praksis svækker eller ligefrem neutraliserer reformernes effekt.

Selvom et sådant styre fremstår som værende midt i en liberaliseringsproces mod demokrati, er der således reelt tale om et autokrati, der ikke er interesseret i at afgive reel magt, men blot regerer efter devisen om at forandre for at bevare. Fraværet af demokratiske fremskridt i Jordan før de arabiske revolter skal derfor heller ikke ses som udtryk for, at der var noget som helst, der var gået galt i reformprocessen. Formået var nemlig først og fremmest at give, især vestlige donorer, indtryk af, at Jordan gjorde fremskridt, samtidigt med at man sikrede, at regimet bevarede magten. I den henseende kan perioden frem til 2011 således betegnes som en succeshistorie.

Denne analytiske forstålsesramme, hvor de jordanske reformer så at sige har et Janus-ansigt, synes fortsat nyttig, hvis man skal forstå de seneste seks års politiske reformer og valg. Da kong Abdallah, der er en stor fan af Jon Stewart, tilbage 2012 besøgte det amerikanske 'The Daily Show' forklarede han, hvordan han var meget optaget af betydningen af demokratiske reformer, og han erklærede, at Jordan stod ved en kritisk korsvej, hvor man inden for de næste fire år skulle være klar til at overgå til et egentligt konstitutionelt monarki med et meningsfuldt parlamentarisk styre.

I dag, seks år efter, er det på den ene side muligt at opregne en lang række reforminitiativer. Der er blevet oprettet en uafhængig valgkommission og en forfatningsret, der er kommet en ny lov om politiske partier, valgloven er ændret, der er nedsat en antikorruptionskommission, og en tredjedel af forfatningen er blevet ændret. På den baggrund kunne det være nærliggende at give Fareed Zakaria ret $\mathrm{i}$ sin erklæring om, at Jordan - sammen med Marokko - fremstår som rollemodeller for, hvordan man i den arabiske verden bør gennemføre politiske reformer.

Andre iagttagere har imidlertid peget på, hvordan mange af reformerne er kosmetiske, og at andre tiltag indebærer, at Jordan i dag ikke er mindre, men mere autokratisk end før 2011. I deres seneste demokratioversigt fra 2016 klassificerer Freedom House da også fortsat landet som 'ikke frit.' (I rapporten for 2017 har Jordan fået prædikatet 'devist frit', red.)

Ziad Abu-Rish og Jillian Schwedler har eksempelvis peget på, at forfatningsændringerne i praksis betyder, at magten over domstolene, udenrigspolitikken og sikkerhed er blevet koncentreret hos kongen, som nu end ikke behøver det tidligere 'gummistempel' fra premierministeren 
til at udstede dekreter eller udpege retspræsident og medlemmer til bl.a. forfatningsdomstolen, senatet (som kan blokere underhuset) samt cheferne for sikkerhedspolitiet, militæret og gendarmeriet.

Gennem forskellige nye bureaukratiske og lovgivningsmæssige procedurer er ytringsfriheden og forsamlingsfriheden blevet yderligere reguleret, og med en ny vidtgående anti-terrorlov fra 2014 kan erklæringer, som kan 'forstyrre' Jordans relation til andre lande, såsom kritik af Jordans alliance med Golf-monarkierne, føre til anklager om terrorisme og fængsling, ligesom kritik af regenten er ulovlig.

\section{Tvetydige valg}

Hvad angår de to seneste parlamentsvalg i 2013 og 2016 og det nylige lokalvalg i august 2017, efterlades man med et tilsvarende tvetydigt billede, hvad angår graden af forandring.

På den ene side hersker der, også blandt internationale observatører, generel enighed, om, at alle disse valg efter de arabiske revolter overordnet set har været frie og lige. Ikke overraskende har den hashemitiske konge således også erklæret, at det står klart, at Jordan bevæger sig ud ad en 'ny demokratisk vej'.

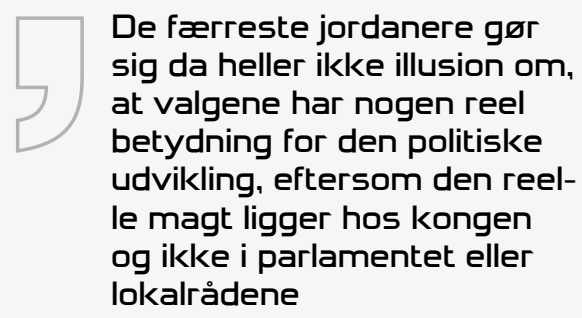

Ved det seneste parlamentsvalg og lokalvalg valgte det Muslimske Broderskabs parti IAF ikke at boykotte som i $2013 \mathrm{og}$ 2010, og de klarede sig endvidere ganske godt. På den anden side synes mange af de velkendte problematikker ved de jordanske valg fortsat aktuelle. Lav valgdeltagelse (i 2016 parlamentsvalget 37 pct. på landsplan og kun 19 pct. i Amman; 2017 lokalvalget 30 pct. på landsplan og 20 pct. i Amman), valgkampe uden reel politisk debat og med kandidater uden partitilhørsforhold eller egentligt politisk program, fragmenterede parlamenter og lokalråd, der domineres af forretningsfolk og repræsentanter for indflydelsesrige stammer og familier, der bakker op om kongefamilien.

Ifølge kritikere er dette ikke nogen tilfældighed, men et resultat af den måde valgsystemet er skruet sammen på. De færreste jordanere gør sig da heller ikke illusion om, at valgene har nogen reel betydning for den politiske udvikling, eftersom den reelle magt ligger hos kongen og ikke i parlamentet eller lokalrådene. Selvom selve valgene er frie, er valgdistrikterne endvidere fortsat præget af 'gerrymandering' i den forstand, at der skal færre stemmer til at få en kandidat valgt i traditionelle regime-loyale områder end i dem, hvor oppositionen står stærkt. Den nye og meget komplicerede valglov gør det desuden vanskeligt at lave nationale lister, hvilket begunstiger individuelle kandidater, som fokuserer på meget snævre lokale spørgsmål.

Hvad angår de nyligt afholdte lokalvalg, som er en del af et decentraliseringsinitiativ fra 2015, der ifølge den officielle retorik har til formål at give jordanere mere reel indflydelse, har skeptikere anført, at den lave valgdeltagelse skyldes, at de nye lokalråd både har meget ringe magt og få midler, at deres indflydelse balanceres af udpegede guvernører, og i eksempelvis Amman vælges borgmesteren slet ikke, men udpeges ligesom en fjerdedel af de øvrige byrådsmedlemmer. 


\section{Fra ét til to broderskaber}

Som nævnt kom protesterne tilbage i 2011 fra vidt forskellige dele af det jordanske samfund, herunder den traditionelt regimeloyale transjordanske befolkning. Her så man bl.a. fremkomsten af den såkaldte Hirak-bevægelse af unge aktivister fra de transjordanske stammer, som ikke blot var kritiske over for regimet, men også den ældre generation inden for stammerne.

Fremkomsten af nye oppositionsaktører betyder dog ikke, at den traditionelle politiske opposition er forsvundet efter de arabiske revolter. Det gælder eksempelvis det Muslimske Broderskab, som dog ikke har været efterladt upåvirket, om end forandringerne ikke har været så dramatiske som de egyptiske brødres op-og nedtur.

Det jordanske broderskab havde oprindeligt en tæt symbiotisk relation til det hashemitiske monarki, men forholdet blev i stigende grad anspændt efter den politiske åbning i 1989. Broderskabets parti IAF indtog rollen som den ledende opposition, men i modsætning til mange andre steder i den arabiske verden vedblev det Muslimske Broderskab med at (få lov til at) virke inden for det formelle politiske system.

I kølvandet på det egyptiske militærkup, der i 2013 væltede præsident Morsi, og Saudi-Arabiens regionale kampagne mod det Muslimske Broderskab, skærpede kong Abdallah imidlertid sin retorik over for Broderskabet, som han i et interview i The Atlantic beskrev som en 'frimurerkult, drevet af ulve i fåreklæder'. I 2014 fulgte der herpå, hvad iagttagere har beskrevet som et regime-orkestreret internt kup i det Muslimske Broderskab.

Ved hjælp af en ny partilov, der krævede, at partier skal forny deres licens, lykkedes det en udbrydergruppe af det Muslimske Broderskab at opnå status som det officielle broderskab, som efterfølgende fik overdraget det 'gamle' broderskabs ejendomme og betragtelige økonomiske midler. Uanset om denne splittelse af det Muslimske Broderskab vitterligt har været egentligt orkesteret af den jordanske sikkerhedstjeneste eller ej, har det uden tvivl været bifaldet fra regimet side. Det 'gamle' broderskab har dog langt fra udspillet sin rolle, og nogle iagttagere mener ligefrem, at IAF's relative valgsucces i 2016 og 2017 vil (gen)sikre dem status som Jordans uofficielle opposition.

\section{Identitetspolitik}

Ligesom det Muslimske Broderskabs omskiftelige relation til det jordanske regime har forholdet mellem den transjordanske og palæstinensiske befolkningsgruppe i Jordan udgjort et klassisk tema i diskussioner om jordansk politik.

Den jordanske befolkning er nogenlunde ligeligt fordelt mellem transjordanere (en person, hvis familie kommer fra det område Jordan udgjorde før 1948) og palæstinensere (en person, hvis familie kommer fra det britiske Palæstina-mandat), hvilket gennem historien har givet anledning til en lang debat dels om (for)fordelingen af rettigheder og privilegier mellem de to befolkningsgrupper og dels om mareridtsscenariet om, at det 'palæstinensiske problem' skulle kunne løses ved at gøre 'Jordan til Palæstina', således som det er blevet foreslået på den israelske højrefløj.

Med tiden er linjerne mellem de to befolkningsgrupper blevet mindre skarpe. Ud over at folk har giftet sig på tværs af disse skel, er der også meget forskellige interesser inden for hver gruppe. Nogle af Jordans mindst og mest velstående er eksempelvis palæstinensere.

Selvom den transjordanske/palæstinen- 


\section{Mens der fra officielt hold ikke længere tales meget om den shiitiske trussel, finder man på samfundsplan ikke blot en stor bekymring for den sekteriske splittelse i regionen, men også ganske stærke anti- shiitiske holdninger. Det gælder især, men ikke kun, blandt salafister og til dels muslimske brødre.}

siske identitetsdebat ikke har spillet samme fremtrædende rolle i tiden efter de arabiske revolter, er den dog ikke forsvundet som et tema, der altid lurer - og kan blive brugt.

Tilbage i 2011 var palæstinensere tilbageholdende med at deltage i demonstrationer af frygt for at blive beskyldt for at være illoyale. Da unge - overvejende transjordanske - aktivister i marts 2011 forsøgte at lave en Tahrir-plads inspireret lejr på en plads i Amman, svirrede det ikke desto mindre pludseligt med rygter $\mathrm{i}$ de transjordanske landområder om, at hovedstaden var ved at blive overtaget af palæstinensere, der ville etablere en islamisk palæstinensisk republik.

Begivenheden kulminerede med, at uropolitiet ryddede lejren, efter at bøller, der beskrev sig om 'loyale over for kongen', havde angrebet de unge. Senest har Jordan oplevet en ny runde af den klassiske 'Jordan er Palæstina'-debat efter, at den amerikanske præsident Donald Trump på en pressekonference med den israelske premierminister Benjamin Netanyahu erklærede sig indifferent i forhold til en én- eller to-statsløsning på Israel/Palæstina-konflikten.

Det gav rystelser i Amman, og de blev ikke mindre, da lederen af det højreorienterede parti, Jewish Home, der er del af den israelske regering, efterfølgende lod forstå, at der jo allerede findes to palæstinensiske stater: én i Gaza og én i Jordan.

Den jordanske identitetspolitik har dog også fået nye dimensioner. Selvom Jordan for 97 pct.'s vedkommende er sunnimuslimer, mens der stort set ikke findes nogen jordanske shiamuslimer, har den regionale debat om shia/sunni-sekterisme også sat sit præg på Jordan.

Sekterisme var ganske vist ikke helt fraværende som tema før de arabiske revolter. Tilbage i 2004 fremsatte kong Abdallah således sin berømte - og berygtede - advarsel mod en fremvoksende 'shia-halvmåne', og omkring 2006-sommerkrigen mellem Hizballah og Israel yndede Jordan sammen med Egypten og Saudi-Arabien meget at tale om den shiitiske trussel. Dengang gav denne sekteriske retorik imidlertid ringe genklang i den jordanske befolkning, der ligesom store dele af den øvrige sunnitiske befolkning i den arabiske verden så positivt på shiitiske Hizballah.

I dag er billedet imidlertid ændret. Mens der fra officielt hold ikke længere tales meget om den shiitiske trussel, finder man på samfundsplan ikke blot en stor bekymring for den sekteriske splittelse i regionen, men også ganske stærke anti-shiitiske holdninger. Det gælder især, men ikke kun, blandt salafister og til dels muslimske brødre. I en PEW-meningsmåling angav 43 pct. af de adspurgte jordanske sunnimuslimer, at shiamuslimer ikke er rigtige muslimer.

\section{Vanskelig balancegang}

Selvom Jordan har været præget af stor grad af kontinuitet siden de arabiske revolter, illustrerer den voksende folkelige fokus på shia/sunni-sekterisme, hvordan landet ikke er upåvirket af de store omvæltninger, som andre dele af Mellemøsten har oplevet siden 2011, herunder 
nogle af Jordans umiddelbare nabolande.

Den tragiske borgerkrig i Syrien har således sat sit præg på Jordan, der har modtaget op i mod 1,4 mio. syriske flygtninge, hvoraf 80.000 bor i Zaatari-flygtningelejren, som i dag er Jordans fjerde største by. De enorme flygtningestrømme udgør en stor udfordring for den jordanske befolkning og økonomi. Ifølge kong Abdallah bruges 25 pct. af det offentlige budget på at hjælpe de mange flygtninge, men iagttagere har samtidigt peget på, hvordan Jordan har haft en vis succes med sit krav om, at international hjælp til de syriske flygtninge i Jordan skal matches med udviklingshjælp, der vil gavne jordanere.

Det er dog heller ikke første gang, at Jordan er modtagerland for store flygtningestrømme, så det nye er snarere, hvor de kommer fra. Gennem sin relativt korte historie har Jordan således modtaget flere bølger af palæstinensiske flygtninge $(1948,1967,1990)$ og i midten af 00 'erne fulgte mellem en halv og en hel million irakiske flygtninge.

Det relativt lille, sårbare og ressourcefattige monarkis placering i et ofte uroligt nabolag har også afspejlet sig i den jordanske udenrigspolitik. Den har historisk været pragmatisk og haft til formål at sikre Jordan - eller nærmere bestemt regimet - økonomisk hjælp og militær beskyttelse og samtidigt afskærme landet fra de mest destabiliserende effekter af regionale omvæltninger. Dette gælder fortsat. Den jordanske Syrien-politik har således primært handlet om at undgå, at den syriske borgerkrig spreder sig til Jordan.

Samtidigt har man været meget bevidst om vigtigheden af at fastholde de gode relationer til USA og Golf-monarkierne, som ud over at være Jordans vigtigste do- norer har været dybt involveret i støtten til den syriske opposition.

I praksis har det givet sig til udtryk i en politik, hvor Jordan har huset træningsfaciliteter for amerikanske og saudisk-støttede syriske oprørere, og samtidigt samarbejdet med såvel pro- som anti-Assad grupper om at stabilisere den syrisk-jordanske grænse.

Hvad angår nabolandet Irak reagerede Jordan ikke blot med skarp retorik efter Islamisk Stats brutale afbrænding af den jordanske pilot Muath Al-Kasasbeh i 2015. Man stillede også med fly til anti-IS-koalitionen. Siden har den jordanske deltagelse dog været neddroslet, hvilket ifølge nogle iagttagere afspejler en bekymring for, at Islamisk Stat vil vende sig mod Jordan via lokale sympatisører, således som det var tilfældet sidste år, hvor gruppen tog ansvar for et angreb i Kerak.

Den aktuelle Golf-krise mellem Qatar og Saudi-Arabien udgør ligeledes en udfordring for Jordan. I lyset af at Jordan i perioden 2012-16 har modtaget fem mia. dollar fra især Saudi-Arabien, valgte Amman ikke overraskende at tilslutte sig den saudiske lejr. Man afstod dog fra at afskære forbindelserne til Qatar, som Jordan ellers har haft et besværligt forhold til. Det er blevet tolket som en konsekvens af, at den saudiske kongefamilie synes at have mistet interessen for Jordan, som ikke har fået fornyet sin hjælpepakke, samtidigt med at Trump har valgt at skære i den traditionelt meget store amerikanske bistand.

Amman har derfor ikke råd til at brænde broerne til Doha, der har betragtelige investeringer i Jordan, og som er en vigtig destination for jordanske gæstearbejdere. Som så mange gange tidligere forsøger man derfor at spille på flere heste. 


\section{Mere kontinuitet end forandring}

I 2002 noterede nu afdøde Fred Halliday, at der findes to forudsigelige og næsten altid forkerte reaktioner på enhver stor international begivenhed: Den ene hævder, at alt er forandret; den anden hævder, at intet er forandret. I stedet mente Halliday, at man burde fokusere på forandringerne i, hvad der fremstår som kontinuitet, og den dybere kontinuitet i umiddelbare forandringer.

Hallidays påmindelse er meget relevant for de seneste seks års udvikling i Mellemøsten. Nogle steder skjuler en umiddelbar kontinuitet, en mere dyberegående forandring. Sisis Egypten er eksempelvis ikke nogen tilbagevenden til Mubaraks form for autokrati.

Selvom Jordan ikke har gennemgået nogen store regimeomvæltninger, har der også været forandringer i det lille hashemitiske kongedømme siden de arabiske revolters begyndelse. Det er dog den påfaldende grad af kontinuitet, der er det mest øjnefaldende, når man kaster blikket på Jordan anno 2017. Det betyder selvsagt ikke, at det vil vedblive med at være sådan, men i de første seks år efter de arabiske revolter har der mestendels været tale om variationer over ganske velkendte temaer. 